\title{
Sickle Cell Anaemia and Deaths in Custody in the UK and the USA
}

\author{
SIMON M. DYSON and GWYNETH BOSWELL \\ Simon Dyson is Director, Unit for the Social Study of Thalassaemia and Sickle \\ Cell, School of Allied Health Sciences, De Montfort University, Leicester; \\ Gwyneth Boswell is Professor, School of Allied Health Professions, \\ University of East Anglia, Norwich
}

Abstract: An unexplained death in custody represents an important focal point for public scrutiny of the criminal justice system, especially when excess deaths occur in those of minority ethnic descent. Sickle cell anaemia is a serious inherited blood disorder disproportionately affecting minority ethnic groups. Sickle cell trait is the genetic carrier state and not an illness. The evidence suggests that the treatment of sickle cell in the criminal justice system is twofold. Justice authorities have misused sickle cell trait to explain away ten sudden deaths, often associated with forced restraint, of AfricanCaribbean people in custody. Meanwhile, seven deaths have been attributable to lack of provision of health care for those prisoners suffering from the illness sickle cell anaemia.

In this article, we examine critically the attraction that explanations based in reductionist versions of genetics have in discourses in the fields of both criminal justice and health. We approach this by considering a case where the two discourses meet. We document the manner in which sudden deaths of people of African-Caribbean descent are explained by the criminal justice authorities. We also look at the way in which sickle cell anaemia is reified as a marker of health issues affecting only people of AfricanCaribbean descent. The two discourses meet when the carrier status sickle cell trait is invoked as indicative of the alleged vulnerability of the male of African-Caribbean descent to death whilst being restrained when in the charge of police, prison, or army officers. We contrast these accounts with other accounts of the lack of sympathy and care for those living with the illness sickle cell anaemia within custody in the USA or the UK. This contrast represents two related points on the same racist and abusive continuum. We attempt to draw out the consequences of the pervasive nature of this discourse both for the treatment of people of AfricanCaribbean descent in the criminal justice system, and for the advancement of treatment and understanding of the condition sickle cell anaemia in the criminal justice system, in health services, and in wider society. The data are drawn from a 30-year timescale, but this merely helps to explain why the pattern has not been noted before, and why each occurrence can be 
represented by the authorities as an exceptional case, rather than part of a systematic discourse.

\section{Sickle Cell Anaemia and Sickle Cell Trait}

Sickle cell anaemia is a serious inherited blood disorder that affects those of African, Caribbean, Indian, Mediterranean, and Arab descent (Serjeant and Serjeant 2001). Genes associated with black skin and genes associated with sickle cell are inherited independently and there is no necessary correspondence between the two. Someone with white skin may carry the gene associated with sickle cell, or even have sickle cell anaemia itself (Lehmann and Huntsman 1974).

One important symptom of sickle cell disorder is the painful episode in which the blood vessels become blocked by red blood cells that distort into sickle shapes, a process called sickling. These painful episodes are potentially life-threatening and are usually treated by a combination of strong painkillers such as diamorphine, intravenous fluids, and sometimes blood transfusions (Rees et al. 2003). Sickle cell trait is the carrier state where a person carries a gene associated with sickle cell, but is not ill themselves. The union of two carriers produces a one-in-four chance in each pregnancy of having a child with the full sickle cell disease (Anionwu and Atkin 2001). The carrier state has been found to offer some protection against cerebral malaria in childhood, and thus the gene flourished in areas of the world that were malarial. The carrier state and the full illness have often been confused, both in legal frameworks (Bowman 1977) and by health staff (Anionwu and Atkin 2001). The World Health Organization (1988) documents how global migration has led to an increase in sickle cell in Europe, and because of the younger age structure of minority ethnic groups, sickle cell anaemia is now the most common genetic condition in England, affecting 1 in 2,380 births (NHS Sickle Cell and Thalassaemia Screening Programme 2002).

In policy terms, sickle cell trait has been misused to reinforce preexisting racial discriminations in other spheres, in employment (Draper 1991), insurance (Bowman 1977), and recruitment to the forces (Wilkie 1993). In contrast, as far as sickle cell anaemia itself is concerned, the lack of urgency in policy has been striking, and health and social care services for treating people with sickle cell have been slow to develop (Prashar, Brozovic and Anionwu 1985; Ahmad and Atkin 1996).

\section{Genetics, Health and Criminal Justice}

Beckett (1999) has shown how in England the function of the coroner system is restricted to confirming the name of deceased, and the place and immediate cause of death. As such, she argues, the function of the coroner inquest into sudden deaths is to "personalize and individualize circumstances of care and control' Beckett (p.271), and State responsibility for the wider circumstances of the death is thus obscured from public scrutiny. The Independent Race and Refugee News Network lists 174 'unexplained 
or mysterious' deaths of black people in 'police, prison and psychiatric custody' between December 1978 and December 2003. From the descriptions, we estimate at least 23 of these deaths to be related to issues of restraint by officials. Public accountability of the State is arguably even more important in the cases of sudden deaths where minority ethnic communities may suspect institutional racism to have played a part in the death.

At the same time, the advent of the so-called 'New Genetics' has given a fresh impetus to claims to explain human behaviour in genetic terms. Much of this discourse can be said to be reductionist in character (see Rose, Lewontin and Kamin (1984); Rose (1997); Kerr, Cunningham-Burley and Amos (1998); Rose and Rose (2000); Lewontin (2000) for critiques of such approaches). Such reductionist explanations have been proposed, not only for physical characteristics, but also for behaviour, including criminal behaviour (Williams 2001). Such discourses have the strategic political purpose and/or consequence of permitting (i) inaction based on the premise that the behaviour, being genetic, is immutable, even 'natural', and (ii) selective social control based on the premise that socially discriminatory responses must be made to naturally occurring differences in phenomena.

However, the type of discourse available may itself depend upon the social context of the production of genetic knowledge. Tapper (1999) suggests that in the case of sickle cell, the knowledge produced is an effect of historically and socially specific social relations. One such discourse identified by Tapper is that of sickle cell as a marker of being a descendant of the so-called negro 'race'. In cases where sickle cell was found in 'white' people of Mediterranean descent, the evidence was treated with extreme scepticism, and investigations centred on the erroneous presumption that carrying the sickle cell trait must, of necessity, index recent African ancestry.

The very genetic knowledge produced is held by Tapper (1999) to be an effect of the social discourses within which knowledge is generated. This draws our attention to the relationship of discourses on crime/genetics and health/genetics. These concerns come together in the case of the attribution of excess deaths of black people in custody to an alleged predisposition to hypoxia (absence of oxygen reaching living tissues) arising from the presence of sickle cell trait in black people. This argument has been advanced, for example, by the then Director of UK Prisons, when questioned on the earlier death in custody of a prisoner of AfricanCaribbean descent in 1995.

\section{Explanations of Deaths in Custody}

On Wednesday 25 March 1998, Richard Tilt, then Director of the Prison Service, was being interviewed by the BBC broadcast journalist Jeremy Paxman on the programme Newsnight. He was questioned about the death of Alton Manning in custody following an inquest verdict that Manning had been unlawfully killed by being placed in a neck hold. Manning had been the third black man to die in UK prisons between October and December 
1995. Tilt raised the possibility that sickle cell disease may have been implicated in the relatively higher number of deaths in custody of people of African-Caribbean descent. The 'research' to which Tilt referred apparently reported that people of African-Caribbean descent were more likely to suffer positional asphyxia (where someone's position prevents them from breathing, often associated with physical restraint techniques) than were whites. Thus it was to be inferred that sickle cell disease might be an explanation for the disproportionate deaths in custody from positional asphyxia whilst being restrained by prison officers. By the Friday, Tilt had apparently apologised 'if my remarks caused any offence', explained that his remarks were based on expert advice given to the Prison Service in 1996, that other experts disagreed with that advice, and that 'what we need to do is to commission some further research' (The Guardian 1998).

The reference to genetics is the ultimate in personalising and individualising the sudden death. It also has the consequence, intended or otherwise, of obscuring from scrutiny the actions or inactions of the State. It is only by subjecting connections between cases to critical examination that patterns can be brought to light, and changes for the better in the criminal justice system can be effected. The example cited stands in a long line of attempts to attribute to sickle cell trait the status of either the cause or a contributory explanatory factor in the death of those of African-Caribbean descent in the custody of the criminal justice system either in the USA or the UK.

As early as 1974, the eminent African-American physician, James Bowman, was asked to be an expert witness in a case in Illinois:

In early 1974 I was involved in expert testimony before a grand jury in a case in Illinois that could lead to an unfortunate precedent for persons with sickle cell trait. A man who had sickle cell trait was allegedly beaten and strangled and suffocated with a blanket by guards in a prison hospital during the process of subduing violent acts of the prisoner. Merely because sickle cells were found intravascularly at post mortem examination, the Cook County Coroner and a consultant medical legal examiner from another state claimed that death was the result of a sickle cell crisis following pressure on the neck which led to hypoxia. The forensic pathologists also stated that the slight nature of some external injuries on the neck led them to believe that if the prisoner had had normal haemoglobin he would not have died. My testimony was that the post mortem findings were compatible with asphyxia and that the presence of pathological cells had no significance. (I also challenged the opinion that severe neck bruises must be present in death from suffocation or strangulation, and offered to demonstrate that I could render the expert medical examiner unconscious without leaving bruises on his neck.) I later learned that the guards were not indicted. Thus the dangerous precedent for legalised murder of persons with sickle cell trait could become established because intravascular sickling is found post mortem in the tissues of most persons with sickle cell trait and a defence lawyer may use the evidence of intravascular sickling in a victim in an attempt to obtain a reduction in the severity of a murder charge of his client. (Bowman 1977, pp.127-8)

In 1976, Edward Dailey died whilst being held in a chokehold whilst in the custody of the Los Angeles Police Department (LAPD). The inquest held 
that sickle cell disorder was a 'significant condition' in explaining his death (Mitchell 1999). In 1981, Charles J. Hill also died having been held in a chokehold whilst in the custody of LAPD and likewise his death was attributed to 'sickle cell crisis' (Mitchell 1999).

In 1992, the family of Donald Fleming of Buffalo, New York, questioned the official version of the cause of death. Fleming was arrested for robbery and died while in police custody. Witnesses claimed that Fleming had been badly beaten. Photographs taken after the autopsy showed serious bruises and other signs of a beating. In fact, the funeral director called the medical examiner to the funeral home because he found a giant gash on Fleming's head, but the medical examiner had reported that there were no marks on Fleming's body. The medical examiner claimed that Fleming died as a result of a heart attack brought on by 'cocaine abuse or sickle cell traits' (Reporter's Committee for Freedom of the Press 2001).

In 1995, in the UK, Denis Stephens was found dead in the punishment block of Dartmoor prison, having been restrained in a body belt for 24 hours. The inquest verdict in December 1997 was accidental death. Dr Fernando, Home Office-appointed Consultant Forensic Pathologist found him 'sickle cell trait positive'. Dr Fernando, together with three other pathologists appointed to represent the different interest groups in the case, agreed sickling could not have been the factor (Inquest 1998). This evidence was heard on 7 November 1997. As we have seen, the death of Alton Manning in 1995 was linked to alleged differences in vulnerability to positional asphyxia, and thereby implicitly linked to sickle cell trait by the Director of the Prison Service in March 1998. Interestingly, therefore, only four months after four medical examiners had independently asserted that sickling would be present in any death where the person had sickle cell trait, this knowledge appeared not to be drawn upon by the national director of a prison service.

In 1998, William Beckley-Lines died whilst in the Royal Green Jackets of the UK army. At the end of a two-mile run William collapsed and died at Catterick Army Barracks. The cause of death was attributed to 'exhaustion, and sickle cell anaemia'. The family paid for a second post mortem which disclosed bruises in his genital area that had not been revealed in the first examination (Farr and Farr 2004).

In 1999, Eddie Bagby died in a boot-camp in Arkansas, USA, when sharp shock exercise and pepper spray were used as a joint punishment. An autopsy revealed that Bagby carried sickle cell trait. The medical examiner ruled that because of the 'several different variables' present at Bagby's death, the manner of his death would remain 'undetermined'. He noted, however, that: 'Because of the short interval between pepper spray exposure and collapse, it is our opinion that the administration of this substance was a contributory factor in the chain of events leading to death' (Arkansas Times 1999).

In 2001, Mario Mallet died in police custody in the USA. At a scheduled press conference, the Milwaukee County Medical Examiner, Jeffrey Jentzen, claimed Mallett became so agitated when scuffling with the police that his heart developed an arrhythmia and ceased to function sometime 
after he was put in the van. Jentzen admitted Mallett never had a heart problem. He also said that an 'undiagnosed sickle cell trait and cold weather' played a part in his death (Milwaukee Journal Sentinel 2002).

Raymond Sterling died in 2003 after being pepper-sprayed whilst in Fort Lauderdale, Florida. The official paramedic report records an offer to the police by the paramedics to take Sterling to the medical centre, though the police report contradicts this. The Broward County Medical Examiner's office claimed that Sterling succumbed to a combination of factors, one of which was sickle cell trait (Miami Herald 2003).

In each of these ten cases cited, the reference to sickle cell trait by the respective authorities has been to a particular aspect of the imputed identity of those of African descent, especially the deep-rooted racist discourse that constructs the black body as inherently a diseased body (Tapper 1999; Wailoo 2001). We wish to argue that this presentational affinity has a number of consequences and functions:

(i) Reference to sickle cell avoids the need for the criminal justice system to confront institutional racism, and further helps to deflect such criticism.

(ii) Reference to sickle cell is one of the many possible strategies for avoidance of confronting racism, or deflecting accusations of racism. Others have included the deployment of some evidence about personality, such as aggression (Jones 1993). Outside of its use in deflecting racism, concern for the health of the prison population is notoriously lacking and has long been seen as a low priority (Sim 1990, 2002; Ramsbotham 2003). (iii) Reference to sickle cell associates sickle cell with criminality. More precisely it deepens the association: sickle cell = black 'race' $=$ criminal. The appeal to the (actually superficial) correlation of sickle cell and black skin helps legitimate the other alleged link, which criminalises black peoples. However, sickle cell is thereby reified as linked only to black peoples; an immutable fact of life; to be accepted as part of the 'natural' order of things. It is also medicalised. Thus the potential for the social advancement of people who have sickle cell anaemia, based on promotion of the right to education; employment; housing; insurance; health and social care, is downplayed or denied. The situation can be further miscast as extreme liberalism in which special favours have to be accorded to black people because of their genetic predispositions. For example, some websites ask provocatively of social liberals whether the alleged vulnerability of black peoples to certain conditions means that those liberals are endorsing a 'whites-only choking policy' (Canada First Immigration Reform Committee 1998).

\section{Care of Those Living with Sickle Cell Disease in Custody}

The readiness to attribute controversial deaths of people of AfricanCaribbean descent in the criminal justice systems of the UK and the USA to carrying a gene associated with sickle cell, stands in marked contrast to the lack of attention to the issue of caring for people with sickle cell anaemia during custodial sentences. Lack of care/self-neglect is one of five possible verdicts for deaths in custody (the others are killed unlawfully, 
misadventure, open or suicide), and Beckett (1999) suggests that coroners are extremely reluctant to return lack of care verdicts, possibly because of concerns that it may trigger civil actions. In this section we document some of the cases where a lack of care of those living with sickle cell anaemia is in evidence.

In the UK in 1983, James Ruddock died after being denied treatment for diabetes and sickle cell anaemia for twelve hours in Kensington police station. The inquest verdict was 'natural causes attributed to self neglect' (Independent Race and Refugee News Network 2002).

In the US in 1997, Anthony Bowman died in Nashville after unsuccessfully begging for treatment for sickle cell disease. The prison had a contract with the doctor responsible for the treatment of Bowman based on incentives to keep costs down (The Tennessean 2000).

In the USA in 1998, came the death of Christopher Jackson, a sickle-cell anaemia patient charged on a minor drug charge, who became ill, lapsed into a coma, and was not hospitalised for three days, despite repeated requests for treatment (World Socialist Web Site 1999).

The family of Kelvin Williams reported being obstructed in their attempts to obtain further information on his death in a Wisconsin prison in 1999. He was discovered lying unconscious in his own vomit and urine. The autopsy report, obtained by journalists, reports that he was 'very ill with sickle cell anaemia' and that there were ten different prescription drugs in his system. The report claims that he died from 'old drugs whose impurities clogged his lungs, plus a variety of new drugs' (Milwaukee Journal Sentinel 2000).

In 1999, a prisoner named Howard died of a sickle cell anaemia crisis at a Kent Hospital in the UK. Howard was admitted in the early hours of a Thursday with all the typical features of a painful sickling episode. He was not seen by a doctor over the weekend despite collapsing with severe diarrhoea, faecal incontinence and vomiting. He died on the Tuesday. Expert evidence criticised the 48-hour gap in medical treatment over the weekend, and the failure to consider life-saving exchange transfusion at any time. The jury returned a verdict of death by natural causes to which negligence contributed.

Amnesty International USA (2003) alleges violation of the rights of women in custody in the USA, and cites sickle cell anaemia as among the conditions where authorities have failed to refer seriously ill prisoners for treatment or have delayed their treatment. The following account is written by a former cellmate of Charisse Shumate, a Californian prisoner living with sickle cell anaemia:

This night, like so many others during my incarceration in cell \#19, I am startled awake by the sound of sobbing. As my eyes adjust to the dim light, I see a crumpled figure leaning against the heavy steel door of our cell trying to summon one of the graveyard-shift guards. The knocking goes on with no response from outside. Soon, all eight women in our cell are awake and banging, yelling, screaming for help. Bitter experience has taught us that our roommate, Charisse Shumate, is in sicklecell anaemia crisis and needs immediate medical attention or she could die. Finally, a face appears at the door. She knows her life depends on convincing the guard that 
she needs immediate medical attention. 'Is this just another convict scam?' he is probably wondering to himself. Summoning up what is left of her strength, she tells him she has medical protocol papers proving what she says. He says he is 'not interested in reading them'. He finally agrees to call the medical department to check out her story and much later help arrives.

Charisse is taken to the infirmary and locked in a holding cell while awaiting transportation to the outside local hospital - a process that can take hours. Charisse knows if she is locked away without water, for hydration, or medication, she may die. So, once again, she tries to explain to the infirmary personnel why she must have immediate medical help. At the hospital, it starts all over again. She has been taken to a hospital not experienced in treating sickle-cell patients and again, she must explain about her disease. All she can do now is pray she receives proper care. (Legal Services for Prisoners with Children 2003)

Charisse Shumate had led a class legal action taken by the Californian Coalition for Women Prisoners in 1995, in an attempt to compel the prison authorities to provide medical care for prisoners with chronic illnesses such as sickle cell anaemia. She died in custody in 2001 having been previously frequently denied prompt treatment for her sickle cell anaemia.

In 2003, Leonard Robinson died from a sickle cell crisis in a correctional centre in Louisiana. His heirs attempted to file a medical malpractice claim against the State of Louisiana, alleging that the prison failed to respond appropriately to his crisis. The State tried to invoke a legal clause requiring a medical panel review because the complaint was not brought by the prisoner himself (May Yen et al. v. Avoyelles Parish Police Jury et al. 2003).

It is clear from these seven cases in the USA and the UK that, as part of a wider context in which care of people living with sickle cell disease is inadequate, the care offered within the criminal justice systems of both the US and the UK falls well short of the minimum standards that might reasonably be required.

\section{The Failure of Sickle Cell as a Potential Explanation}

It is very worrying to see the misuse of genetics to explain/excuse deaths of black males in custody. The controversy raises a wide range of issues about the criminal justice system, about policies regarding sickle cell, about the appeal of genetic explanations and about the use of research as a policy end in itself.

The appeal to the genetics of sickle cell as evidence of the (allegedly) uniquely flawed black body draws attention away from the wider social reasons why males of African-Caribbean descent are disproportionately in custody in the first instance, including the racisms of the criminal justice system. From the framing of nationality laws (Rushdie 1982; Sondhi 1987) and immigration policies (Sivanandan 1982[1976]; Kundnami 2000), through styles of policing of black communities (Cashmore and McLaughlin 1991; Macpherson 1999), to the micro-politics of being processed through the criminal justice system (Cavadino and Dignan 2002) to differential treatment of black detainees (Commission for Racial Equality 2003): each stage is replete with sociological reasons for the over- 
representation of people of African-Caribbean descent. Moreover, African-Caribbean people are more likely to be compulsorily detained in psychiatric institutions, even when no more likely to be a danger to themselves and others (Davies et al. 1996) and psychiatrists are even more liable to view detained African-Caribbean people as dangerous, than are the police (Rogers 1990).

Moreover, comments on the role of sickle cell trait as a contributory, complicating or confounding factor in explaining the sudden death of a person of African descent in the criminal justice system draw attention away from the role of racisms in the immediate context of restraint (Are African-Caribbeans more likely to be provoked by racist taunts of prison officers? Are African-Caribbeans more likely to be disproportionately perceived to require restraint because of racial stereotypes of the allegedly physically powerful black male (Webbe 1998)? Are they more likely to be subjected to restraint? Are they more likely to be subjected to restraint earlier in the process of any rising interpersonal tension? Are they more likely to be subjected to more violent restraint than other groups?).

The introduction of sickle cell appeals to a potential explanation out of all proportion to the issue. Sickle cell anaemia affects 1 in 300 people of African-Caribbean descent in the UK and the USA. Unless one were to make a totally implausible case as to why those with sickle cell anaemia should be disproportionately in custody in the first instance, then sickle cell anaemia could only be a possible explanation, even in theory, of 1 in 300 deaths in custody. One would then be led to ask why successive officials are attempting to explain the exception of one rather than the rule of the other 299.

However, it seems more likely that the spokespeople for the criminal justice systems and others are confusing sickle cell anaemia and sickle cell trait. Sickle cell trait, remember, is the carrier state in which the person is usually perfectly healthy. Although sickle cell trait may have relevance in extremes of oxygen deprivation, requiring care, for example in the administration of anaesthetics, as soon as the argument moves to the carrier state rather than the full sickle cell anaemia we move down an order of magnitude in any assessment of the likelihood of there being an effect. In any case, as was agreed by the four pathologists in the Denis Stephens case cited above, evidence of sickling of red blood cells in post mortems has no relationship to sickling of cells during life:

.. the presence of widespread intravascular sickling in post-mortem or in surgical specimens has no relationship to the amount (if any) of intravascular sickling that may have been present while the tissue(s) were living, for intravascular sickling may arise as an agonal event or after death as a result of tissue hypoxia. (Bowman 1977, pp.122-3)

However, even supposing that sickle cell trait could be shown to have an effect, sickle cell trait is only carried by a minority of peoples of AfricanCaribbean descent, that is about $10 \%$. Once more we would be left to ask why an issue affecting a minority of African-Caribbean peoples was being 
asked to bear the load of an argument claiming a generalised difference between people of African-Caribbean descent and others.

\section{Why is a Genetic Argument Used?}

The controversies outlined so far lead us to ask why a (flawed) genetic argument is so readily turned to as a possible explanation. There seem to be at least five inter-related reasons for this.

First, it draws attention away from forms of racism in provision of services. In the US, insurance companies raised their premiums by $50 \%$, even though there was no actuarial evidence for this; major airlines fired black employees with sickle cell trait, even though they had only just begun to hire African-Americans; and despite rigorous trials demonstrating that pilots with sickle cell trait showed no effects in even the most strenuous conditions, the US Department of Defence screened out applicants with sickle cell trait (Bowman 1977). More recently, apparently benign employer concern for employees with sickle cell trait working in dangerous industries has led to disproportionate layoffs for black employees rather than action on environmental and occupational health hazards (Draper 1991). In this respect the current issue is but the latest illustration of such misuses of genetics, from a justification of colonialism (Cavalli-Sforza, Menozzi and Piazza 1994) to a linkage of 'race' and IQ, which allegedly 'explained' differences in educational achievement and hence employment opportunities (Demaine 1989).

Second, it leaves unexamined difficult measures which would otherwise demand to be addressed were non-genetic reasons to come to the fore. In this instance, apart from the over-representation of males of AfricanCaribbean descent in custody and the racisms of some prison staff, there is the issue of the health and safety of prison officers and police who are expected to restrain prisoners, and the extent to which they are given adequate training to carry out their job safely. One US trainer in restraint, who acted as a defence witness in the cases of the Los Angeles motorist Rodney King, blames the abandonment of chokeholds by the LA Police Department in the 1980s following political pressure, and the subsequent reliance on police batons as the only means of restraint in violent confrontations, for cases such as that of King (Meyer 1994).

Third, an appeal to genetics is often an appeal to nature. Since at no time in the debate have the various authorities of the respective criminal justice systems suggested that they reacted to this alleged knowledge of vulnerability by issuing special measures to offer protection to males of African-Caribbean descent, one can only assume that the purpose of raising the issue is to tutor the rest of us that we must accept disproportionate deaths, since being based on genetics they represent the natural order of things. But a genetic basis to an issue does not make an event unalterable (Rose and Rose 1986).

Fourth, the cause of promoting a wider understanding of sickle cell anaemia also continues to be damaged by the comments of various coroners, police, and prison officials. This is not merely because it has 
further promulgated the misunderstanding of the distinction between sickle cell anaemia and sickle cell trait. It has been very difficult for people with sickle cell anaemia to be open about their situation in a context, not only of societal racism, but also where, as an issue grounded in genetics, it is especially vulnerable to even the narrowest definitions of racism which specify that to qualify as racism the discrimination must be based on presumed biological difference (Mason 1994). The current treatment for people with sickle cell anaemia suffering severe painful crises is based on opiate drugs. Hospital staff in both the US and the UK have been known to be slow to administer, or even to withhold, such pain-relieving drugs because of a popular racist stereotype which associates black peoples with drug misuse (Hill 1994; Anionwu and Atkin 2001). This is likely to be even more the case in prisons, where health care has historically been poor and where drug use generally has reached epidemic proportions in some prisons.

Fifth, the call by authorities for further research is disingenuous. It serves the purpose of cooling out critics, playing for time, and enabling some face to be saved. The discrepancy between the time frames of the media, policy processes, and the time scales of research means that little scrutiny is given to whether research is ever commissioned and, if so, what bearing it has on the critical events of the past. In the case of the UK Prison Service, no such research was ever commissioned (Narey 2000). Statistically, sickle cell could not possibly explain the highly raised overrepresentation of deaths of African-Caribbean males in custody. Removing racisms in the criminal justice system and removing racist prison officers from their posts are more pressing priorities (Chouhan 2003; Commission for Racial Equality 2003). Calls for further research draw attention away from the fact that good treatment practices and policies are available (National Institutes of Health 2002; Rees et al. 2003) but that these are currently not consistently applied in the wider community, let alone in the prison system. This suggests that what is more vital is not more research, but action for the benefit of peoples of African-Caribbean descent, on the basis of the research that does exist. The call for research dovetails into another ongoing abuse - the over-researching of minority ethnic communities to the extent of research fatigue (Ahmad 1993) and to evergrowing resentment that the solution to any problem seen to be affecting minority ethnic peoples is more research conducted upon them, rather than addressing inequalities based on materialism and racisms that are already known (Ahmad 1999).

\section{Conclusion}

In conclusion, there has been a worryingly long series of comments on deaths in custody that cite sickle cell trait by way of reference to supposedly genetic bases to differences in behaviour or in responses to physical conditions. They draw us away from the serious issues of addressing racisms in the criminal justice system. Within a wider picture of low priority given to prisoner health needs, and to those of black and ethnic minority 
groups generally, there is an equally worrying failure to attend to the health needs of detainees who suffer with sickle cell anaemia. Sickle cell as a health issue has apparently acquired the status of being regarded as a symbolic benchmark of the wider inequities faced in health services by African-Americans (Tapper 1999) and by British African-Caribbeans (Anionwu and Atkin 2001). It could be argued that the issue of deaths in custody has the same function for the black community, as a marker of the persistence of racism in institutions of social control such as the police, the Prison Service and the armed forces.

It might be supposed that we are dealing with small numbers of cases and/or that the problems identified are historical. However, the numbers of peoples living with sickle cell anaemia is projected to rise in the next ten years (Streetly, Maxwell and Mejia 1997). Moreover, many states in the US (National Institutes of Health 2002) test all new born children for sickle cell disease, a test that will also reveal those who have sickle cell trait, that is, those who are carriers. From 2004, such neonatal screening tests will be offered to all newborn infants in England (NHS Sickle Cell and Thalassaemia Screening Programme 2002). In the future, therefore, any person with the illness sickle cell anaemia will have been identified as such, and will have their illness documented in medical notes. This should mean there is no excuse for the respective police, prison and armed forces authorities to be in ignorance of the health needs of those in their care. Moreover, as a by-product of the neonatal screening test, those who are carriers, that is, those with sickle cell trait, will also have been identified. This more systematic recording of the prevalence of the sickle cell trait, again likely to be documented in notes, will mean increased numbers vulnerable to the types of racist discourse we have described in this article.

The gene for sickle cell haemoglobin is an evolutionary adaptation to protect against certain types of malaria. However, neither sickle cell anaemia nor sickle cell trait protect against racism, nor against a failure to learn from history, nor indeed, according the testimony of Bowman (1977) cited above, against legalised murder.

\section{References}

Ahmad, W.I.U. (1993) 'Making black people sick: "race", ideology and health research', in: W.I.U. Ahmad (Ed.), 'Race' and Health in Contemporary Britain, Buckingham: Open University Press.

Ahmad, W.I.U (1999) 'Ethnic statistics: better than nothing or worse than nothing?', in: D. Dorling and S. Simpson (Eds.), Statistics in Society: The Arithmetic of Politics, London: Arnold.

Ahmad, W.I.U. and Atkin, K. (1996) 'Ethnicity and caring for a disabled child: the case of children with sickle cell or thalassaemia', British Journal of Social Work, 26, 755-75.

Amnesty International USA (2003) Medical Neglect of Women in US Prisons (Factsheet Number 4) (available online at: http://www.amnestyusa.org (accessed 19 December 2003)).

Anionwu, E. and Atkin, K. (2001) The Politics of Sickle Cell and Thalassaemia, Buckingham: Open University Press. 
Arkansas Times (1999) The Death of Eddie Bagby (available online at: http://www.arktimes. com/mara/080699mara.html (accessed 23 April 2004)).

Beckett, C. (1999) 'Deaths in custody and the inquest system', Critical Social Policy, 19(2), 271-80.

Bowman, J. (1977) 'Genetic screening programs and public policy', Phylon, 38, $117-42$.

Canada First Immigration Reform Committee (1998) Race Doesn't Matter They Say (Number 109) (available online at: http://www.canadafirst.net/current_issues/cih-109. html (accessed 28 April 2004)).

Cashmore, E. and McLaughlin, E. (Eds.) (1991) Out of Order: Policing Black People, London: Routledge.

Cavadino, M. and Dignan, J. (2002) The Penal System: An Introduction, 3rd ed., London: Sage.

Cavalli-Sforza, L.L., Menozzi, P. and Piazza, A. (1994) The History and Geography of Human Genes, New Jersey: Princeton University Press.

Chouhan, K. (2003) 'Race issues in probation', in: D. Ward, J. Scott and M. Lacey (Eds.), Probation: Working for Justice, Oxford and New York: Oxford University Press.

Commission for Racial Equality (2003) Racial Equality in Prisons: A Formal Investigation by the CRE into HM Prison Service of England and Wales, London: Commission for Racial Equality.

Davies, S., Thornicroft, G., Leese, M., Higginbotham, A. and Phelan, M. (1996) 'Ethnic differences in risk of compulsory psychiatric admission among representative cases of psychosis in London', British Medical Journal, 312, 533-7.

Demaine, J. (1989) 'Race, categorization and educational achievement', British Journal of Sociology of Education, 10(2), 195-214.

Draper, E. (1991) Risky Business: Genetic Testing and Exclusionary Practices in the Hazardous Workplace, Cambridge: Cambridge University Press.

Farr, L. and Farr, M. (2004) Their Story: William N Beckley-Lines (available online at: http://freespace.virgin.net/lynn.farr/their\%20Story.htm (accessed 27 April 2004)).

Hill, S.A. (1994) Managing Sickle Cell Disease in Low Income Families, Philadelphia: Temple University Press.

Independent Race and Refugee News Network (2002) Black Deaths in Custody (available online at: http://www.irr.org.uk (accessed 26 April 2004)).

Inquest (1998) Report on the Death in Prison Custody of Denis Stevens, INQUEST 89-93 Fonthill Road, London N4 3JH (available online at: http://www.inquest.gn.apc.org (accessed 26 April 2004)).

Jones, S. (1993) The Language of the Genes, London: Harper Collins.

Kerr, A., Cunningham-Burley, S. and Amos, A. (1998) 'The new genetics and health: mobilizing lay expertise', Public Understanding of Science, 7, 41-60.

Kundnani, A. (2000) 'Stumbling on: race, class and England', Race and Class, 41(4), $1-8$.

Legal Services for Prisoners with Children (2003) Stories from Inside: Charisse Shumate, San Francisco, California (available online at: http://www.prisonerswithchildren.org (accessed 19 December 2003)).

Lehman, H. and Huntsman, R.G. (1974) Man's Haemoglobins, 2nd ed., Philadelphia: JP Lippincott.

Lewontin, R. (2000) It Ain't Necessarily So: The Dream of the Human Genome and Other Illusions, London: Granta Books.

Macpherson, W. (1999) The Stephen Lawrence Inquiry: Report of an Inquiry by Sir William Macpherson, Cm. 4262-1.

Mason, D. (1994) 'On the dangers of disconnecting race and racism', Sociology, 28(4), $845-58$. 
May Yen et al. v. Avoyelles Parish Police Jury et al. (2003) State of Louisiana Court of Appeal, Third Circuit 03-603 (available online at: http://www.la3circuit.org/opinions/2003/11/ 110503/03-0603opi.pdf (accessed 27 April 2004)).

Meyer, G. (1994) After Rodney King: What Have We Learned? (available online at: http:// home.earthlink.net/ gregmeyer/articles/king1pg3.html (accessed 24 May 2001)).

Miami Herald (2003) Police Spray Linked to Death (available online at: http://www. miami.com.mld/miamiherald (accessed 19 December 2003)).

Milwaukee Journal Sentinel (2000) Inmates' Families Get No Answers (available online at: http://www.jsonline.com/news/state/oct00/2prisfam23102200.asp (accessed 23 April 2004)).

Milwaukee Journal Sentinel (2002) Group Looks for Answers in Death of Mallett (available online at: http://www.jsonline.com/news/metro/jan02/11362.asp (accessed 23 April 2004)).

Mitchell, M.R. (1999) Sixteen Los Angeles Police Department Chokehold Deaths 1975-1982 (available online at: http://www.geocities.com/CapitolHill/6416/review16.html (accessed 26 April 2004)).

Narey, M. (2000) Personal communication, 27 April 2000 (Ref 00/417/DG), London: HM Prison Service Headquarters.

National Institutes of Health (2002) The Management of Sickle Cell Disease, 4th ed., Bethesda, MD.: National Institute of Health, National Heart, Lung and Blood Institute, Division of Blood Diseases and Resources.

NHS Sickle Cell and Thalassaemia Screening Programme (2002) Screening Policies: Newborn Screening Programme, Policy 2002 (available online at: http://www.kcl-phs. org.uk/haemscreening/ (accessed 28 January 2004)).

Prashar, U., Brozovic, M. and Anionwu, E.N. (1985) Sickle-Cell Anaemia: Who Cares?, London: Runnymede Trust.

Ramsbotham, D. (2003) Prisongate: The Shocking State of Britain's Prisons and the Need for Visionary Change, London: Free Press.

Rees, D., Olujohungbe, A.D., Parker, N., Stephens, A., Telfer, P. and Wright, J. (2003) 'Guidelines for the management of the acute painful crisis in sickle cell disease', British Journal of Haematology, 120(5), 744-52.

Reporter's Committee for Freedom of the Press (2001) 'Autopsy photos are often used to refute official conclusions', The News Media and the Law, 25(2), 9 (available online at: http://www.rcfp.org/news/mag/25-2/cov-autopsyp.html (accessed 26 April 2004)).

Rogers, A. (1990) 'Policing mental disorder: controversies, myths and realities', Social Policy and Administration, 24(3), 226-36.

Rose, H. and Rose, S. (Eds.) (2000) Alas Poor Darwin: Arguments Against Evolutionary Psychology, London: Jonathan Cape.

Rose, S. (1997) Lifelines: Biology, Freedom, Determinism, Harmondsworth: Penguin.

Rose, S. and Rose, H. (1986) 'Less than human nature: biology and the new right', Race and Class, XXVII(3), 47-66.

Rose, S., Lewontin, R. and Kamin, L. (1984) Not in Our Genes, Harmondsworth: Penguin.

Rushdie, S. (1982) 'The new empire within Britain', New Society, 9 December (reprinted in: S. Rushdie (1991), Imaginary Homelands: Essays \& Criticism, 1981 to 1991, London: Granta in association with Penguin).

Serjeant, G. and Serjeant, B. (2001) Sickle Cell Disease, 3rd ed., Oxford: Oxford University Press.

Sim, J. (1990) Medical Power in Prisons: The Prison Medical Service in England 1774-1989, Milton Keynes and Philadelphia: Open University Press.

Sim, J. (2002) 'The future organisation of prison health care: a critical analysis', Critical Social Policy, 22(2), 300-23.

Sivanandan, A. (1976) Race, class and the State, republished in: A. Sivanandan (Ed.) (1982), A Different Hunger; Writings on Black Resistance, London: Pluto Press. 
Sondhi, R. (1987) Divided Families: British Immigration Control in the Indian Subcontinent, London: Runnymede Trust.

Streetly, A., Maxwell, K. and Mejia, A. (1997) Sickle Cell Disorder in Greater London: A Needs Assessment of Screening and Care Services. Fair Shares for London, London: United Medical and Dental Schools, Department of Public Health Medicine.

Tapper, M. (1999) In the Blood: Sickle Cell Anaemia and the Politics of Race, Philadelphia: University of Pennsylvania Press.

The Guardian (1998) 'Prison boss says sorry for suffocation remark', 28 March.

The Tennessean (2000) 'Judge halts prison's contract with doctor', 26 June (available online at: http://www.tennessean.com/sii/00/06/26/cca26.shtml (accessed 23 April 2004)).

Wailoo, K. (2001) Dying in the City of the Blues: Sickle Cell Anaemia and the Politics of Race and Health, Chapel Hill, North Carolina: University of North Carolina Press.

Webbe, A. (1998) 'Ethnicity and mental health', Psychiatric Care, 5(1), 12-16.

Wilkie, T. (1993) Perilous Knowledge: The Human Genome Project and its Implications, London: Faber and Faber.

Williams, K. (2001) Textbook on Criminology, Oxford, New York: Oxford University Press.

World Health Organization (1988) The Haemoglobinopathies in Europe: Combined Report of Two WHO Meetings (Document EUR/ICP/MCH 110), Copenhagen: WHO Regional Office for Europe.

World Socialist Web Site (1999) New York: Nassau County Jail Guards Stomp Man to Death, 26 January 1999 (available online at: http://www.wsws.org/articles/1999/jan1999/ ny-j26.shtml (accessed 23 April 2004)).

Date submitted: July 2004

Date accepted: November 2004 